Научная статья

УДК 379.85

DOI https://doi.org/10.24866/VVSU/2073-3984/2021-3/091-107

О. Ю. Гуревич ${ }^{1}$

А. Ю. Кононов ${ }^{2}$

Владивостокский государственный университет экономики и сервиса

Владивосток. Россия

\title{
Экспорт услуг в сфере туризма
}

В статье проведён анализ проблемы экспорта услуг в сфере туризма в современных условиях в контексте мирового и отечественного опыта. Цель работы выявить актуальные направления поддержки экспорта услуг в сфере туризма. Для достижения поставленной цели были определены и решены конкретные задачи. В ходе исследования осуществлена оценка последствий пандемии COVID-19 для мировой торговли. Выявлена роль третичного сектора в условиях восстановления мировой экономики. На заключительном этапе были систематизированы факторы, влияющие на конкурентоспособность экспортёров туристских услуг, определены инструменты и стратегии для повышения конкурентоспособности предприятий сферы услуг, правительств и институтов. В условиях повышения фискальной нагрузки на федеральные и региональные бюджеты, а также трансформации структуры спроса выделены приоритетные виды услуг на экспорт. Исследование теоретических аспектов проводилось с помощью таких методов научного познания, как метод сравнения, индукция и дедукция, методы актуализации, системного анализа, классификации, абстрагирование и конкретизация. Практическая значимость работы состоит в систематизации и актуализации теоретических подходов к анализу экспорта услуг в сфере туризма как важнейшего показателя конкурентоспособности в новых условиях.

Ключевые слова и словосочетания: COVID-19, экспорт услуг, пандемия, проблемы, возможности, туризм, Российская Федерация, пункт назначения.

\section{O.Yu. Gurevich}

\section{A.Yu. Kononov}

Vladivostok State University of Economics and Service Vladivostok. Russia

1 Гуревич Ольга Юрьевна - магистрант кафедры туризма и экологии; e-mail: gurevich@primclub.ru

2 Кононов Артем Юрьевич - канд. экон. наук, доцент кафедры туризма и экологии; e-mail: artem.kononov@vvsu.ru 


\section{Export of services in the field of tourism}

The article analyzes the problem of export of services in the field of tourism in modern conditions in the context of world and domestic experience. The purpose of the work is to identify current areas of support for the export of services in the field of tourism. To achieve this goal, specific tasks were identified and solved. The study assessed the impact of the COVID-19 pandemic on global trade. The role of the tertiary sector in the global economic recovery is revealed. At the final stage, the factors affecting the competitiveness of tourism service exporters were systematized, and tools and strategies for improving the competitiveness of service enterprises, governments and institutions were identified. Also, in the context of an increase in the fiscal burden on the federal and regional budgets, as well as the transformation of the demand structure, priority types of services for the export of tourist services are identified. The study of theoretical aspects was carried out using such methods of scientific knowledge as the method of comparison, induction and deduction, methods of actualization, system analysis, classification, abstraction and concretization. The practical significance of the work is to systematize and update the theoretical approaches to the analysis of the export of services in the field of tourism as the most important indicator of competitiveness in the new conditions.

Keywords: COVID-19, services exports, pandemic, challenges, opportunities, tourism, The Russian Federation, destination.

\section{Введение}

На фоне экономических потрясений, вызванных COVID-19, 2020 год в целом оказался позитивным для мировой торговли [1]. Основная поддержка в этом отношении пришлась на экономики стран Восточной Азии, чей ранний успех в смягчении последствий пандемии позволил им быстрее восстановиться и адаптироваться к новым реалиям. В то же время поведение потребителей существенно изменилось: увеличился спрос на продукцию здравоохранения, цифровые услуги, оборудование для связи и домашнего офиса, а снизился, например, на транспортное оборудование, международные перевозки и гостиничные услуги.

Позитивные тенденции последних месяцев 2020 года усилились в начале 2021 года. В 1 квартале 2021 года объем мировой торговли товарами и услугами вырос примерно на 4\% по сравнению с предыдущим кварталом и примерно на $10 \%$ по сравнению с предыдущим годом. Важно отметить, что объёмы мировой торговли в 1 квартале 2021 года оказались выше докризисного уровня, увеличившись примерно на $3 \%$ по сравнению с 1 кварталом 2019 года.

Вместе с тем, в 1 квартале 2021 года объем торговли товарами был выше, чем до пандемии, но объем торговли услугами остался существенно ниже средних показателей, как следует из данных практически всех основных мировых экономик (табл. 1). 
Динамика мировой торговли, \%

\begin{tabular}{|c|c|c|c|c|c|}
\hline \multirow[t]{2}{*}{ Экономика } & \multirow[t]{2}{*}{ Показатель } & \multicolumn{2}{|c|}{1 кв. 2021 к 2020 г. } & \multicolumn{2}{|c|}{1 кв. 2021 к 2019 г. } \\
\hline & & Импорт & Экспорт & Импорт & Экспорт \\
\hline \multirow[t]{2}{*}{ Россия } & Товары & +15 & +14 & +9 & -10 \\
\hline & Услуги & +7 & -5 & -30 & -28 \\
\hline \multirow[t]{2}{*}{$\mathrm{EC}$} & Товары & +13 & +14 & +1 & +6 \\
\hline & Услуги & -1 & +7 & -13 & -6 \\
\hline \multirow[t]{2}{*}{ США } & Товары & +14 & +16 & +7 & 0 \\
\hline & Услуги & +10 & +3 & -14 & -18 \\
\hline \multirow[t]{2}{*}{ КНР } & Товары & +22 & +20 & +20 & +25 \\
\hline & Услуги & +3 & +27 & -23 & +22 \\
\hline \multirow[t]{2}{*}{ Индия } & Товары & +45 & +26 & +10 & +7 \\
\hline & Услуги & +14 & +2 & +2 & -3 \\
\hline \multirow[t]{2}{*}{ Япония } & Товары & +11 & +16 & -2 & +5 \\
\hline & Услуги & +5 & -2 & -2 & -24 \\
\hline \multirow[t]{2}{*}{ Республика Корея } & Товары & +18 & +19 & +9 & +12 \\
\hline & Услуги & -2 & +13 & -20 & -2 \\
\hline \multirow[t]{2}{*}{ ЮАР } & Товары & +25 & +36 & -4 & +31 \\
\hline & Услуги & -1 & -26 & -37 & -62 \\
\hline \multirow[t]{2}{*}{ Бразилия } & Товары & +22 & +17 & +4 & +8 \\
\hline & Услуги & -2 & +2 & -31 & -15 \\
\hline
\end{tabular}

Примечание: составлено по [1].

При этом в рамках торговли услугами можно выделить четыре основных подсектора:

- услуги, связанные с товарами;

- транспортные услуги;

- туризм;

- прочие коммерческие услуги [2].

Последние могут быть дополнительно подразделены на услуги связи, финансовые, страховые, строительные, компьютерные и информационные услуги, роялти и лицензионные сборы, другие деловые услуги и личные, культурные и рекреационные услуги.

В таблице 2 показаны годовые изменения в мировой торговле услугами в разбивке по данным подсекторам. 
Рост мировой торговли услугами в годовом исчислении, \%

\begin{tabular}{|l|c|c|c|c|}
\hline \multicolumn{1}{|c|}{ Показатель } & 1 квартал 2020 & 2 квартал 2020 & 3 квартал 2020 & 4 квартал 2020 \\
\hline Коммерческие услуги & -7 & -28 & -24 & -19 \\
\hline Транспорт & -7 & -29 & -24 & -13 \\
\hline Туризм & -25 & -82 & -69 & -71 \\
\hline $\begin{array}{l}\text { Услуги, связанные с } \\
\text { товарами }\end{array}$ & -8 & -22 & -15 & -6 \\
\hline $\begin{array}{l}\text { Прочие коммерческие } \\
\text { услуги }\end{array}$ & 0 & -6 & -1 & -2 \\
\hline
\end{tabular}

Примечание: составлено по [3].

В то же время до 2020 года во всем мире услуги составляли две трети объёма экономического производства, более половины рабочих мест и около четверти прямого экспорта. Именно на сферу услуг также приходились две трети общего роста производительности в развивающихся странах [4]. Таким образом, экспорт услуг важнейший показатель конкурентоспособности в новых условиях. Увеличение экспорта услуг может смягчить дефицит платёжного баланса, диверсифицировать стратегию развития. Создание условий, благоприятствующих торговле услугами, будет иметь ключевое значение для дальнейшего восстановления после экономического спада. Туризм как наиболее пострадавший сегмент представляет собой в данном случае один из наиболее наглядных индикаторов.

Цель исследования - анализ путей развития экспорта услуг в сфере туризма.

Для реализации поставленной цели были решены следующие задачи:

- оценка последствий пандемии COVID-19 для мировой торговли;

- определение роли третичного сектора и сферы туризма, в частности, в условиях восстановления мировой экономики;

- систематизация инструментов и стратегий для повышения конкурентоспособности сферы туристских услуг на мировом рынке.

Предмет, источниковая база исследования, противоречия в имеющихся исследованиях и авторская позиция

Единого классификационного перечня услуг не существует. Согласно трактовке Международного валютного фонда (МВФ) услуги включают распределительные услуги (например, транспорт), услуги производителей (банковское дело и финансы), социальные услуги (образование) и личные услуги (общественное питание) [5]. ВТО разделяет услуги на основе Классификации основных продуктов $\mathrm{OOH}[6]$.

Однако независимо от типа используемой классификации все услуги имеют общие характеристики (неосязаемость и невидимость, которые затрудняют измерение реальной стоимости услуг и оценку их вклада в производство). 
При этом, как подчеркивают Хукман и Костецки, услуги жизненно важны для функционирования любой экономики, поскольку они влияют на конкурентоспособность и выполняют посредническую функцию в производственном процессе [7]. Подобно капиталу, услуги играют ключевую роль в качестве детерминанты производительности факторов производства, облегчая пространственно-временную реализацию транзакции [8].

В результате, по словам Гани и Хоума, существует связь между высоким ростом услуг и высоким общим экономическим ростом, хотя причинноследственная связь не может быть однозначно установлена [9]. Тем не менее, рост сектора услуг обычно обусловлен сокращением бедности, что сопровождается созданием новых рабочих мест и косвенным воздействием на потребление.

В контексте текущих условий можно отметить, что, поскольку основанные на фактических данных экономические исследования влияния COVID-19 на международную торговлю услугами находятся только на ранних стадиях, большая часть трудов представлена в виде комментариев, перспектив и кратких изложений политики.

При этом в работе Болдуин и Томиура COVID-19 представлен как шок спроса и предложения (в отличие от финансового кризиса 2008 года, который был вызван главным образом расстройством спроса) [10]. Авторы описали пандемию как состояние глобального производственного кризиса и искажённых международных цепочек поставок, которые, вероятно, замедлят совокупный мировой спрос, существенно сократив глобальную торговлю как товарами, так и услугами.

Экономисты ВТО также прогнозируют, что сокращение торговли из-за COVID-19 превысит торговые потери, вызванные финансовым кризисом 20082009 годов [11]. Это может быть связано с тем, что сектор услуг продемонстрировал большую устойчивость во время кризиса 2008 года, однако в настоящее время пострадал от пандемии из-за ограничений на поездки и транспорт. Помимо торговли конечными товарами и услугами, ограничения на передвижение людей и транспорт почти нарушили цепочки создания стоимости производства и услуг [12].

Для моделирования потенциального воздействия COVID-19 на мировой ВBП и торговлю было предложено использовать модель общего равновесия [13]. Модель экспериментирует с четырьмя шоками, основанными на опыте предыдущих пандемий: недоиспользование капитала и рабочей силы, увеличение затрат на реализацию международной торговли, снижение спроса на туристические услуги и нарушение деятельности, требующей близости между людьми.

Абай и соавторы использовали исторические данные и данные поиска Google в реальном времени для оценки влияния COVID-19 на спрос на отели, транспорт, туризм, розничную торговлю, услуги доставки в 182 странах [14]. Временные и пространственные различия в данных показывают, что спрос на отели сократился более чем на $63 \%$.

Такого рода тенденции демонстрируют необходимость непрерывной актуализации теоретических и практических подходов к анализу инструментов и стратегий для повышения конкурентоспособности сервисных предприятий, 
федеральных и региональных властей и институтов в контексте экспорта туристских услуг.

Методы исследования. Исследование проводилось с помощью таких методов научного познания, как метод сравнения, индукция и дедукция, методы актуализации, системного анализа, классификации, абстрагирование и конкретизация.

\section{Основная часть}

Согласно отчету организации экономического сотрудничества и развития «Тренды и политика в области туризма 2020» [15], туристский экспорт является экономически значимым и оказывает большее влияние на внутреннюю экономику по сравнению с другими секторами экспорта. На каждый 1 долл. США расходов международных туристов в странах ОЭСР в среднем приходится около 89 центов внутренней добавленной стоимости (по сравнению с 81 центом на общий экспорт).

Туризм обеспечивает в среднем 4,4\% ВВП всех стран ОЭСР и составляет $21,5 \%$ экспорта услуг в странах ОЭСР. Вместе с тем, в общемировом охвате, по данным отчёта Всемирного совета по туризму и путешествиям, совокупный вклад туризма в мировой валовой внутренний продукт оценивается на уровне $10,4 \%$, или около 8,3 трлн долл. США (3,2\% - оценка прямого вклада туризма без учета косвенных и индуцированных эффектов на экономику), при этом 1 из 10 рабочих мест в мире создаётся именно в сфере туризма [16].

Согласно Стратегии развития туризма в Российской Федерации в период до 2035 года [17], объёмы доходов от международного туризма по категории «поездки» (без учета затрат на транспорт) в мире составляли 475 млрд долл. США в 2000 году (около 700 долл. США на 1 туриста), а в 2017 году - 1310 млрд долл. США (около 1000 долл. США на 1 туриста).

В условиях пандемии COVID-19, согласно данным ежегодного доклада Всемирного совета по путешествиям и туризму, потери отрасли составляют почти в 4,5 трлн долл. США. Вклад сектора в ВВП снизился на 49,1\%, при том что мировой ВВП сократился всего на 3,7\% в прошлом году. Отчёт также показывает падение расходов на международные поездки, которые снизились на 69,4\% по сравнению с предыдущим годом. Расходы на внутренние поездки сократились на 45\% [18].

В контексте России можно отметить, что, по данным Банка России [19], в 2020 году экспорт услуг составил 46 886,43 млн долл. США, из них в категории «деловые поездки» - 1964,32 млн долл. США, 889,86 млн долл. США - в категории «личные поездки», в состав которых в соответствии с Методикой формирования показателя 2.9.87 «Объем экспорта услуг Российской Федерации», утвержденной Приказом ЦБ РФ от 26 апреля 2019 года № ОД-965, входят поездки с туристическими, оздоровительными, познавательными, спортивными, религиозными и иными частными целями.

При этом 119,52 млн долл. США составили туристические услуги в сфере организованного туризма за 1-4 кварталы 2020 года в соответствии с отчётом ЦБ РФ «Экспорт отдельных видов услуг по субъектам Российской Федерации» [20].

Число иностранных граждан, въехавших в Российскую Федерацию с целью туризма, согласно данным Погранслужбы ФСБ России, формируемым на основе Перечня «Цели поездок», представлено в табл. 3.

96 
Число въездных туристских поездок иностранных граждан в Российскую Федерацию

\begin{tabular}{|c|c|c|c|c|}
\hline Год & Число & Динамика, чел. & $\begin{array}{c}\text { Доля от общего } \\
\text { числа въездов ино- } \\
\text { странных граждан в } \\
\text { РФ, \% }\end{array}$ & Динамика, \% \\
\hline 2017 & 3809733 & - & 11,89 & - \\
\hline 2018 & 4201330 & 391597 & 12,91 & 1,02 \\
\hline 2019 & 5061696 & 860366 & 15,4 & 2,49 \\
\hline 2020 & 336000 & -4725696 & 3,5 & $-11,9$ \\
\hline
\end{tabular}

Примечание: составлено авторами по [21].

В то же время стратегия развития туризма в РФ на период до 2035 года определяет следующие цели применительно к экспорту туристских услуг: рост объёма туристской индустрии от 3158 млрд руб. до 16306 млрд руб. в 2035 году; увеличение экспорта туристских услуг Российской Федерации от 8,9 млрд долл. США до 28,6 млрд долл. США к 2035 году; увеличение инвестиций в сферу туризма в 3 раза к 2035 году [17]. Такого рода политика привела к тому, что на текущий момент Россия находится на 21 месте по числу прибытий международных туристов (табл. 4).

Таблица 4

Международный туризм, количество прибытий, 2019 г.

\begin{tabular}{|l|c|c|}
\hline \multicolumn{1}{|c|}{ Страна } & Число прибытий, ед. & Доля от общемирового значения, \% \\
\hline США & 166009000 & 7.280678 \\
\hline КНР & 162538000 & 7.12845 \\
\hline Испания & 126170000 & 5.533454 \\
\hline Мексика & 97406000 & 4.271947 \\
\hline Италия & 95399000 & 4.183926 \\
\hline Польша & 88515000 & 3.882014 \\
\hline Венгрия & 61397000 & 2.692696 \\
\hline Венгрия & 60021000 & 2.632349 \\
\hline Гонконг & 55913000 & 2.452184 \\
\hline Турция & 51747000 & 2.269475 \\
\hline Великобритания & 40857000 & 1.791871 \\
\hline Таиланд & 39916000 & 1.750601 \\
\hline
\end{tabular}


Территория новых возможностей. Вестник ВГУЭС. 2021. № 3

Окончание табл. 4

\begin{tabular}{|l|c|c|}
\hline \multicolumn{1}{|c|}{ Страна } & Число прибытий, ед. & Доля от общемирового значения, \% \\
\hline Германия & 39563000 & 1.73512 \\
\hline Макао & 39406000 & 1.728234 \\
\hline Греция & 34005000 & 1.491362 \\
\hline Дания & 32903000 & 1.443031 \\
\hline Канада & 32430000 & 1.422287 \\
\hline Австрия & 31884000 & 1.398341 \\
\hline Япония & 31882000 & 1.398253 \\
\hline Малайзия & 26101000 & 1.144715 \\
\hline Российская Федерация & 24419000 & 1.070947 \\
\hline
\end{tabular}

Примечание: составлено авторами по [22].

Соответствующий показатель по критерию поступлений от международного туризма располагает Россию на 22 месте в мире (табл. 5).

Таблица 5

Международный туризм, поступления (в текущих долларах США), 2019 г.

\begin{tabular}{|l|c|c|}
\hline \multicolumn{1}{|c|}{ Страна } & Поступления, долл. США & Доля от общемирового значения, \% \\
\hline США & 233461000000 & 12.86149 \\
\hline Франция & 71011000000 & 3.912032 \\
\hline Таиланд & 65082000000 & 3.585401 \\
\hline Германия & 58201000000 & 3.206323 \\
\hline Италия & 51910000000 & 2.859748 \\
\hline Япония & 49206000000 & 2.710784 \\
\hline Австралия & 47953000000 & 2.641755 \\
\hline Турция & 42350000000 & 2.333083 \\
\hline Макао & 39714000000 & 2.187865 \\
\hline ОАЭ & 38413300781 & 2.116208 \\
\hline Гонконг & 32697000000 & 1.801294 \\
\hline Индия & 31661000000 & 1.744221 \\
\hline Республика Корея & 26217000000 & 1.444308 \\
\hline Мексика & 25847000000 & 1.423924 \\
\hline Австрия & 25288000000 & 1.393129 \\
\hline
\end{tabular}


О.Ю. Гуревич, А.Ю. Кононов. Экспорт услуг в сфере туризма

Окончание табл. 5

\begin{tabular}{|l|c|c|}
\hline \multicolumn{1}{|c|}{ Страна } & Поступления, долл. США & Доля от общемирового значения, \% \\
\hline Португалия & 24736000000 & 1.362719 \\
\hline Греция & 23003000000 & 1.267247 \\
\hline Малайзия & 22199000000 & 1.222954 \\
\hline Швейцария & 21257000000 & 1.171059 \\
\hline Саудовская Аравия & 19849000000 & 1.093492 \\
\hline Индонезия & 18404000000 & 1.013886 \\
\hline Российская Федерация & 17670000000 & 0.973449 \\
\hline
\end{tabular}

Примечание: составлено авторами по [23].

Понимание того, какие факторы влияют на конкурентоспособность экспортёра услуг (в частности, экспорта туристских услуг), имеет решающее значение для определения мер и действий, которые необходимо предпринять предприятиямэкспортерам, федеральным и региональным властям, а также отраслевым институтам.

Общие рекомендации в этом отношении можно представить в виде SWOTанализа (табл. 6). Однако данный результат не является ни исчерпывающим, ни непосредственно применимым к каждой отдельно взятой стране (от быстрорастущих экономик до небольших стран, не имеющих выхода к морю). Сильные и слабые стороны могут варьироваться в зависимости от страны или сектора.

\section{Таблица 6}

SWOT-анализ факторов определения конкурентоспособности экспорта услуг

\begin{tabular}{|c|c|}
\hline Сильные стороны & Слабые стороны \\
\hline $\begin{array}{l}\text { • сравнительные преимущества в трудоемких } \\
\text { услугах } \\
\text { • сильная предпринимательская культура } \\
\text { • относительно низкие затраты на рабочую } \\
\text { силу } \\
\text { • исторические и культурные связи с потен- } \\
\text { циальными целевыми рынками } \\
\text { • обилие исторических, художественных, } \\
\text { культурных и природных богатств (особенно } \\
\text { важно для туризма) }\end{array}$ & $\begin{array}{l}\text { • низкое качество человеческого капитала } \\
\text { • посредственная цифровая и физическая ин- } \\
\text { фраструктура } \\
\text { • низкие стандарты внутреннего регулирова- } \\
\text { ния (зарегулированность доступа на внешние } \\
\text { рынки) } \\
\text { • ограниченные финансовые и администра- } \\
\text { тивные ресурсы } \\
\text { • отсутствие адекватных инструментов и ме- } \\
\text { тодологий для анализа рынка } \\
\text { • дефицит информации } \\
\text { • политическая нестабильность } \\
\text { • низкая узнаваемость бренда и трудности в } \\
\text { установлении доверия со стороны междуна- } \\
\text { родных контрагентов }\end{array}$ \\
\hline
\end{tabular}


Окончание табл. 6

\begin{tabular}{|c|c|}
\hline Сильные стороны & Слабые стороны \\
\hline & $\begin{array}{l}\text { • отсутствие регулирующих институтов или } \\
\text { их чрезмерная фрагментация } \\
\text { • неэффективная бизнес-среда } \\
\text { • сосредоточенность ресурсов на торговле } \\
\text { товарами } \\
\text { • слабое соблюдение законов об авторском } \\
\text { праве }\end{array}$ \\
\hline Возможности & Угрозы \\
\hline $\begin{array}{l}\text { • языковые навыки } \\
\text { • географическое положение } \\
\text { • высокий спрос на профильных специалистов } \\
\text { • большая диаспора на потенциальных целе- } \\
\text { вых рынках }\end{array}$ & $\begin{array}{l}\text { • увеличение операционных издержек } \\
\text { • усиление конкуренции } \\
\text { • усиление протекционистских настроений • } \\
\text { утечка мозгов }\end{array}$ \\
\hline
\end{tabular}

Помимо определения факторов влияния на конкурентоспособность экспортера услуг в условиях повышения фискальной нагрузки на федеральные и региональные бюджеты, а также трансформации структуры спроса важно определить приоритетные виды (подсекторы) услуг для экспорта туристских услуг.

В соответствии со Стратегией развития туризма в России на период до 2035 года [17] приоритетными видами туризма являются детский, культурнопознавательный, горнолыжный, экологический, круизный и деловой туризм. Мировой тенденцией считается рост интереса к культурно-познавательному и экологическому туризму, ориентированному на рекреационную деятельность на природе, что делает Российскую Федерацию еще более привлекательным туристским направлением для российских и иностранных туристов. Таким образом, предлагается в качестве приоритетных туристских подсекторов выделить:

1. Экологический и горнолыжный (активный) туризм.

Согласно Международному обществу экотуризма (TIES), экотуризм определяется как «ответственное путешествие в природные районы, которое сохраняет окружающую среду, поддерживает благополучие местного населения и включает интерпретацию и образование» [24]. Экотуризм должен приносить прямые финансовые выгоды для местного населения и ориентироваться на сохранение природных ресурсов. По данным ОЭСР, природный туризм имеет большой потенциал для экономического роста [25]. Это один из наиболее быстрорастущих сегментов мировой индустрии туризма и один из немногих секторов экспорта услуг, в которых даже бедные страны уже имеют или могут развивать явное сравнительное преимущество благодаря своим природным ресурсам. Согласно экспертам ОЭСР, рекламная кампания природного туризма может быть дорогостоящей для национальных поставщиков туристских услуг. В связи с этим со стороны государства требуется поддержка экспортеров туристских услуг в виде целевых субсидий, взаимосвязанных с объемом сгенерированного спроса на туристский продукт Российской Федерации 100 
и его прироста в отчетном году, которые могут быть направлены на рекламу в медиа- и интернет-пространстве.

Согласно прогнозам ОЭСР, в период после COVID-19 природный туризм будет одним из популярных видов туризма, поскольку открытые пространства, удаленность, чистота воздуха, свежесть воды приобретут большую ценность в глазах путешественников, а в охраняемых территориях может ожидаться значительный рост числа посетителей.

По данным международного рейтинга конкурентоспособности стран в туристском секторе (ТTCI), опубликованного Всемирным экономическим форумом, по показателю «Природные ресурсы» Россия занимает 34 место из 140 стран (3,8 балла из 7, максимальный показатель у Мексики - 6 баллов) [26]. Основные регионы развития экологического туризма в России сосредоточены в Сибирском, Дальневосточном, Приволжском, Уральском, Северо-Западном, СевероКавказском и Южном федеральных округах.

Ожидается, что рынок экотуризма продолжит расти значительными темпами до 2025 года. Глобальный годовой доход от экотуризма оценивается в диапазоне от 800 млрд долл. США (The International Ecotourism Society, TIES) до 1 трлн долл. США (UNWTO). Экотуризм в настоящее время растет от 10 (TIES) до $12 \%$ (UNWTO) в годовом исчислении [27] и является наиболее быстрорастущим сегментом индустрии туризма.

2. Культурно-познавательный и гастрономический туризм.

По данным международного рейтинга конкурентоспособности стран в туристском секторе (ТTCI), опубликованного Всемирным экономическим форумом, по показателю «Культурное наследие и деловые поездки» Россия занимает 18 место из 140 стран (3,7 балла из 7). Максимальные показатели у Китая (7 баллов), Франции $(6,8)$, Испании $(6,7)$, Италии, Германии и Японии $(6,5)[26]$.

Развитие культурно-познавательного туризма, в частности мест культурного наследия, может стать катализатором роста туристического потока и, как следствие, развития туристического сектора. По данным доклада «Мировой рынок культурного туризма» [28], размер рынка культурного туризма сохранил среднегодовые темпы роста на уровне 7,24\% - с 497 млн долл. США в 2014 году до 613 млн долл. США в 2019 году. Аналитики рынка считают, что в ближайшие несколько лет объем рынка культурного туризма будет еще больше увеличиваться. Ожидается, что к 2025 году объем рынка культурного туризма достигнет 920 млн долл. США.

По данным Международной ассоциации кулинарного туризма, в среднем «гастрономические» туристы тратят около 1200 долл. США за поездку, при этом более одной трети (36\%, или 425 долл. США) их бюджета на поездку идет на мероприятия, связанные с едой. Однако, если кулинария является основной причиной поездки, как правило, туристы тратят значительно большую сумму своего общего бюджета на поездку (около 50 \%) на мероприятия, связанные с едой [29]. При этом гастрономический туризм приносит $25 \%$ экономической прибыли туристическому направлению и 53\% путешественников (leisure travelers) потенциально являются «гастрономическими» (food travelers) [30].

В результате в рамках отмеченной парадигмы можно также выделить определенные инструменты повышения комплексной конкурентоспособности дестинации в контексте экспорта туристских услуг (табл. 7). 
Инструменты и стратегии для повышения конкурентоспособности экспорта услуг сервисных предприятий

\begin{tabular}{|c|c|}
\hline Цель & Инструмент \\
\hline \multicolumn{2}{|r|}{ Внутренние факторы } \\
\hline $\begin{array}{l}\text { Развитие человеческого } \\
\text { капитала }\end{array}$ & $\begin{array}{l}\text { • организация учебных курсов для работников } \\
\text { • заключение соглашений с учебными заведениями о профес- } \\
\text { сиональной практике студентов }\end{array}$ \\
\hline Развитие сервиса & $\begin{array}{l}\text { • повышение стандартов обслуживания } \\
\text { • предоставление туристических пакетов, включающих допол- } \\
\text { нительные услуги: местный транспорт и услуги гида, а также } \\
\text { услуги в области образования или здравоохранения }\end{array}$ \\
\hline $\begin{array}{l}\text { Улучшение международно- } \\
\text { го авторитета }\end{array}$ & $\begin{array}{l}\text { • получение сертификатов качества международного стандарта } \\
\text { • создание или модернизация веб-сайтов } \\
\text { • участие в мероприятиях и выставках }\end{array}$ \\
\hline \multicolumn{2}{|r|}{ Внешние факторы } \\
\hline Улучшение инфраструктуры & $\begin{array}{l}\text { •лоббирование правительства в целях улучшения инфраструкту- } \\
\text { ры - автомобильные и железные дороги }\end{array}$ \\
\hline $\begin{array}{l}\text { Улучшение предпринима- } \\
\text { тельской среды }\end{array}$ & $\begin{array}{l}\text { •лоббирование правительства в целях улучшения ситуации в } \\
\text { здравоохранении }\end{array}$ \\
\hline
\end{tabular}

При этом экспорт услуг требует широкого участия властей в контексте поддержания общественных благ и предоставления общественных услуг, формирования деловой среды. Инструменты и стратегии федеральных и региональных властей для повышения конкурентоспособности комплексного потенциала экспорта услуг представлены в табл. 8.

Таблица 8

\section{Инструменты и стратегии федеральных и региональных властей для повышения конкурентоспособности комплексного потенциала экспорта услуг}

\begin{tabular}{|l|l|}
\hline \multicolumn{1}{|c|}{ Цель } & \multicolumn{1}{|c|}{ Инструмент } \\
\hline Развитие инфраструктуры & \begin{tabular}{l}
\multicolumn{1}{c|}{ • расширение доступа к автомобильному, железнодорожному и } \\
воздушному транспорту (особенно к соединению культурных / \\
исторических / природных достопримечательностей, больниц, \\
деловых центров, учебных центров с гостиничными номерами); \\
• повышение качества автомобильного и железнодорожного \\
транспорта; \\
• повышение качества больниц и образовательных центров
\end{tabular} \\
\hline $\begin{array}{l}\text { Развитие человеческого } \\
\text { капитала }\end{array}$ & $\begin{array}{l}\text { • введение учебных курсов в сфере туризма; } \\
\text { •содействие овладению иностранными языками (английский и } \\
\text { другие языки целевых рынков) }\end{array}$ \\
\hline
\end{tabular}

102 
Окончание табл. 8

\begin{tabular}{|l|l|}
\hline \multicolumn{1}{|c|}{ Цель } & \multicolumn{1}{c|}{ Инструмент } \\
\hline $\begin{array}{l}\text { Сокращение информацион- } \\
\text { ной асимметрии }\end{array}$ & $\begin{array}{l}\text { • более тесное взаимодействие с учреждениями и предприятиями; } \\
\text { • сбор информации о потребностях, эффективности и интересах; } \\
\text { • сбор информации о потенциальных целевых рынках }\end{array}$ \\
\hline Продвижение & $\begin{array}{l}\text { • заключение соглашений с соседними странами, которые явля- } \\
\text { ются более конкурентоспособными в сфере туристической дея- } \\
\text { тельности, с тем чтобы предлагать комбинированные туристиче- } \\
\text { ские пакеты для увеличения экспорта туристических услуг; } \\
\text { • продвижение туристической индустрии страны с помощью ин- } \\
\text { формационно-просветительских программ, телевизионной рек- } \\
\text { ламы, участия в выставках и интернет-рекламы; } \\
\text { • улучшение репутации поставщиков через содействие использо- } \\
\text { ванию международных сертификатов; } \\
\text { • более тесное взаимодействие с учреждениями и предприятиями }\end{array}$ \\
\hline
\end{tabular}

Важно отметить роль общественных институтов, которые выступают в качестве связующего звена между предприятиями и властями. Институты играют ключевую роль в обеспечении того, чтобы частный сектор развивал экспортный потенциал услуг и чтобы власти проводили надлежащую и эффективную политику, направленную на повышение конкурентоспособности экспорта услуг. Инструменты и стратегии институтов для повышения конкурентоспособности комплексного потенциала экспорта услуг представлены в табл. 9.

Таблица 9

Инструменты и стратегии институтов для повышения конкурентоспособности комплексного потенциала экспорта услуг

\begin{tabular}{|l|l|}
\hline \multicolumn{1}{|c|}{ Цель } & \multicolumn{1}{c|}{ Инструмент } \\
\hline \multicolumn{2}{|c|}{ Уровень воздействия: институты } \\
\hline $\begin{array}{l}\text { Снижение фрагментации и } \\
\text { поддержание общей стратегии }\end{array}$ & $\begin{array}{l}\text { • создание единого или ограниченного числа учреждений, } \\
\text { каждое из которых обладает конкретными компетенциями в } \\
\text { области регулирования и координируется одним органом в } \\
\text { целях обеспечения общей стратегии; } \\
\text { • укрепление переговорного потенциала путем расширения } \\
\text { представительства/членства, улучшения человеческого ка- } \\
\text { питала и сокращения отсутствия координации }\end{array}$ \\
\hline \multicolumn{2}{|c|}{ Уровень воздействия: предприятия } \\
\hline $\begin{array}{l}\text { Улучшение международного } \\
\text { авторитета }\end{array}$ & $\begin{array}{l}\text { • участие в выставках для продвижения индустрии туризма; } \\
\text { • налаживание сотрудничества с иностранными учрежде- } \\
\text { ниями на целевых рынках }\end{array}$ \\
\hline $\begin{array}{l}\text { Поддержка развития качества } \\
\text { сервиса }\end{array}$ & $\begin{array}{l}\text { ө оказание поддержки рынку в виде информации о целевых } \\
\text { рынках, стимулирования инноваций, коллективного участия } \\
\text { в выставках, выдачи сертификатов качества }\end{array}$ \\
\hline
\end{tabular}


Окончание табл. 9

\begin{tabular}{|l|l|}
\hline \multicolumn{1}{|c|}{ Цель } & \multicolumn{1}{c|}{ Инструмент } \\
\hline Улучшение деловой среды & $\begin{array}{l}\text { • снижение административной нагрузки за счет сокращения } \\
\text { количества документов, необходимых для получения лицен- } \\
\text { зий и разрешений, и обеспечения исполнения контрактов; } \\
\text { • реализация функции единого ориентира для решения ад- } \\
\text { министративных проблем }\end{array}$ \\
\hline $\begin{array}{l}\text { Поддержка развития человече- } \\
\text { ского капитала }\end{array}$ & \begin{tabular}{l} 
өрганизация учебных курсов \\
\hline \multicolumn{2}{|c|}{ Уровень воздействия: правительственные организации }
\end{tabular} \\
\hline асимметрии информационной & $\begin{array}{l}\text { •реализация функции единого голоса для лоббирования в } \\
\text { пользу индустрии туризма; } \\
\text { • проведение обзоров текущего состояния сектора внутрен- } \\
\text { него туризма и его основных конкурентов за рубежом, а } \\
\text { также основных барьеров для роста въездного туризма и } \\
\text { экспорта туристических услуг с целью понимания потреб- } \\
\text { ностей и недостатков отрасли и разработки адекватных } \\
\text { стратегий для удовлетворения потребностей и решения про- } \\
\text { блем }\end{array}$ \\
\hline
\end{tabular}

Как видно из приведенного анализа, доступный инструментарий раскрывает различные уровни воздействия и преследует различные цели. При этом отмеченные результаты для всех стейкхолдеров в значительной степени перекликаются, и наиболее эффективных результатов можно будет добиться при максимально согласованной всеми сторонами политике.

\section{Выводы}

Таким образом, на фоне экономических потрясений, вызванных COVID-19, 2020 год оказался в целом позитивным для мировой торговли. Вместе с тем, в 1 квартале 2021 года объем торговли товарами был выше, чем до пандемии, но объем торговли услугами остался существенно ниже средних показателей.

Экспорт услуг - важнейший показатель конкурентоспособности в новых условиях. Увеличение экспорта услуг может смягчить дефицит платёжного баланса, диверсифицировать стратегию развития. Создание условий, благоприятствующих торговле услугами, будет иметь ключевое значение для дальнейшего восстановления после экономического спада. Туризм (как наиболее пострадавший сегмент) служит в данном случае наглядным индикатором.

Понимание того, какие факторы влияют на конкурентоспособность экспортёра услуг (в частности, экспорта туристских услуг), имеет решающее значение для определения мер и действий, которые необходимо предпринять предприятиям-экспортерам, федеральным и региональным властям, а также отраслевым институтам. Общие рекомендации в этом отношении были представлены в виде SWOT-анализа. В ходе анализа были систематизированы инструменты и стратегии для повышения конкурентоспособности экспорта услуг сервисных предпри- 
ятий, а также инструменты и стратегии федеральных и региональных властей и институтов для повышения конкурентоспособности комплексного потенциала экспорта услуг.

При этом экологический и горнолыжный (активный), а также культурнопознавательный и гастрономический виды туризма в ходе исследования выделены в качестве приоритетных видов услуг для экспорта туристских услуг, что особенно важно в условиях повышения фискальной нагрузки на федеральные и региональные бюджеты, а также трансформации структуры спроса.

1. Global Trade Update May 2021. - Текст: электронный // United Nations Conference on Trade and Development: [сайт]. - URL: https://unctad.org/system/files/officialdocument/ditcinf2021d2_en.pdf (дата обращения: 14.06.2021).

2. BPM6 Compilation Guide. - Текст: электронный // International Monetary Fund: [сайт]. URL: https://www.imf.org/external/pubs/ft/bop/2014/pdf/guide.pd (дата обращения: 14.06.2021).

3. World trade primed for strong but uneven recovery after COVID-19 pandemic shock. Текст: электронный // World Trade Organization: [сайт]. - URL: https://www.wto.org/english/news_e/pres21_e/pr876_e.htm (дата обращения: 14.06.2021).

4. Bruno Antunes. Services sector vital to COVID-19 есоnomic recovery. - Текст: электронный // UNCTAD: [сайт]. - URL: https://unctad.org/news/services-sector-vital-covid-19economic-recovery (датаобращения: 14.06.2021).

5. Lehmann A., Tamirisa N. T., Wieczorek, J. International Trade in Services: Implications for the IMF - Текст: электронный // International Monetary Fund: [сайт]. - URL: https://www.imf.org/external/pubs/ft/pdp/2003/pdp06.pdf (дата обращения: 14.06.2021).

6. Classifications on Economic Statistics. - Текст: электронный // United Nations: [сайт]. URL: https://unstats.un.org/unsd/classifications/Econ/Structure(дата обращения: 14.06.2021).

7. Hoekman B. M., Kostecki M. M. The Political Economy of the World Trading System. The WTO and Beyond. - Oxford: Oxford University Press, 2009. - 547 p.

8. Sáez S. Trade in Services Negotiations: A Guide for Developing Countries. - Текст: электронный // World Bank: [сайт]. - URL: https://openknowledge.worldbank.org/ bitstream/handle/10986/2481/555480PUB0Trad1PI19845893001PUBLIC1.pdf (дата обращения: 14.06.2021).

9. Ghani E., Homi K. The Service Revolution - Текст: электронный // World Bank: [сайт]. URL: https://openknowledge.worldbank.org/_ bitstream/handle/10986/10187/ 545950BRI0EP140Box349423B01PUBLIC1.pdf (дата обращения: 14.06.2021).

10. Baldwin R., Tomiura E. Thinking ahead about the trade impact of COVID-19 // Economics in the Time of COVID-19, 2020. - P. 59-72.

11. Trade set to plunge as COVID-19 pandemic upends global economy. - Текст: электронный // World Trade Organization: [сайт]. - URL: https://openknowledge.worldbank.org/bitstream/handle/10986/10187/545950BRI0EP140B ox349423B01PUBLIC1.pdf (дата обращения: 14.06.2021).

12. Fukunari K., Shandre M.T., Dionisius N. Pandemic (COVID-19) Policy, Regional Cooperation and the Emerging Global Production Network // Asian Economic Journal. - 2020. №34(1). - P. 3-27.

13. Maliszewska M., Mattoo A., van der Mensbrugghe D. The Potential Impact of COVID-19 on GDP and Trade. - Текст: электронный // Policy Research Working Paper: [сайт]. URL: https://openknowledge.worldbank.org/bitstream/handle/10986/33605/The-Potential- 
Impact-of-COVID-19-on-GDP-and-Trade-A-Preliminary-Assessment.pdf (дата обращения: 14.06.2021).

14. Abay K., Tafere K., Woldemichael A. Winners and Losers from COVID-19. Global Evidence from Google Search. - Текст: электронный // Policy Research Working Paper: [сайт]. - URL: https://openknowledge.worldbank.org/bitstream/ handle/10986/33852/Winners-and-Losers-from-COVID-19-Global-Evidence-from-GoogleSearch.pdf (дата обращения: 14.06.2021).

15. OECD Tourism Trends and Policies 2020. Tourism trends. Top policy priorities. Key policy messages. - Текст: электронный // Organization for Economic Co-operation and Development: [сайт]. - URL: https://www.oecdru.org/zip/cfe-2020-39-sum_v2-ru.html (дата обращения: 14.06.2021).

16. Economic Impact Reports. - Текст: электронный // World Travel \& Tourism Council: [сайт]. - URL: https://wttc.org/Research/Economic-Impact (дата обращения: 14.06.2021).

17. Стратегия развития туризма в Российской Федерации на период до 2035 года. Текст: электронный // Федеральное агентство по туризму: [сайт]. - URL: https://tourism.gov.ru/upload/iblock/298/\%D0\%A1\%D1\%82\%D1\%80\%D0\%B0\%D1\%82 \%D0\%B5\%D0\%B3\%D0\%B8\%D1\%8F\%20\%D1\%80\%D0\%B0\%D0\%B7\%D0\%B2\%D0 \%B8\%D1\%82\%D0\%B8\%D1\%8F\%20\%D1\%82\%D1\%83\%D1\%80\%D0\%B8\%D0\%B7\% D0\%BC\%D0\%B0\%20\%D0\%BD\%D0\%B0\%20\%D0\%BF\%D0\%B5\%D1\%80\%D0\%B8\% D0\%BE\%D0\%B4\%20\%D0\%B4\%D0\%BE\%202035\%20\%D0\%B3\%D0\%BE\%D0\%B4\% D0\%B0.pdf (дата обращения: 14.06.2021).

18. WTTC research reveals global Travel \& Tourism sector suffered a loss of almost US $\$ 4.5$ trillion in 2020 due to the impact of COVID-19. - Текст: электронный // World Travel \& Tourism Council: [сайт]. - URL: https://wttc.org/News-Article/Global-TandT-sectorsuffered-a-loss-of-almost-US4-trillion-in-2020 (дата обращения: 14.06.2021).

19. Внешняя торговля Российской Федерации услугами в структуре расширенной классификации услуг (по методологии платежного баланса) за 2020 год. - Текст: электронный // Центральный банк Российской Федерации: [сайт].- URL: https://cbr.ru/vfs/statistics/credit_statistics/trade/63-trade_20.xls (дата обращения: 14.06.2021).

20. Экспорт отдельных видов услуг по субъектам Российской Федерации за 2020: [сайт]. - URL: https://cbr.ru/vfs/statistics/credit_statistics/trade/exp_services_reg_20.xlsx (дата обращения: 14.06.2021).

21. Число въездных туристских поездок иностранных граждан в Российскую Федерацию (Росстат). - Текст: электронный // Федеральное агентство по туризму: [сайт]. - URL: https://tourism.gov.ru/contents/analytics/statistics/chislo-vezdnykh-turistskikh-poezdokinostrannykh-grazhdan-v-rossiyskuyu-federatsiyu/ (дата обращения: 14.06.2021).

22. International tourism, number of arrivals. - Текст: электронный // World Bank: [сайт]. URL: https://data.worldbank.org/indicator/ST.INT.ARVL (дата обращения: 14.06.2021).

23. International tourism, receipts (current US\$). - Текст: электронный // World Bank: [сайт]. - URL: https://data.worldbank.org/indicator/ST.INT.RCPT.CD (дата обращения: 14.06.2021).

24. What Is Ecotourism? - Текст: электронный // The international ecotourism society: [сайт]. - URL: https://ecotourism.org/what-is-ecotourism/ (дата обращения: 14.06.2021).

25. OECD Tourism Trends and Policies 2020. - Текст: электронный // Organization for Economic Co-operation and Development: [сайт].- URL: https://read.oecd.org/10.1787/6b47b985-en?format=pdf (дата обращения: 14.06.2021).

26. Travel \& Tourism Competitiveness Index. - Текст: электронный // World economic forum: [сайт]. - URL: https://reports.weforum.org/travel-and-tourism-competitiveness- 
report-2019/rankings/https://read.oecd.org/10.1787/6b47b985-en?format=pdf (дата обращения: 14.06.2021).

27. Global Ecotourism Trends and Suggestions. - Текст: электронный // The International Ecotourism Society: [сайт]. - URL: https://ace.aua.am/files/2019/09/The-GlobalEcotourism-Market-The-Trends-How-Armenia-Can-Tap-into-Opportunities-Jon-

Bruno.pdfhttps://read.oecd.org/10.1787/6b47b985-en?format=pdf （дата обращения: 14.06.2021).

28. Global Cultural Tourism Market Report 2020. - Текст: электронный // Business industry reports: [сайт]. - URL: https://www.businessinudstryreports.com/report/109717/globalcultural-tourism-market-report-2019https://read.oecd.org/10.1787/6b47b985en?format=pdf (дата обращения: 14.06.2021).

29. Culinary (or gastronomic) tourism. - Текст: электронный // Caribbean Tourism organization: $\quad$ [сайт]. - $\quad$ URL: https://www.onecaribbean.org/content/ files/CulinaryCaribbeanNicheMarkets.pdfhttps://read.oecd.org/10.1787/6b47b985en?format=pdf (дата обращения: 14.06.2021).

30. What is food tourism? - Текст: электронный // World Food Travel Association: [сайт]. URL: $\quad$ https://worldfoodtravel.org/what-is-food-tourism/https://read.oecd.org/10.1787/ 6b47b985-en?format=pdf (дата обращения: 14.06.2021).

\section{References}

1. Vneshnyaya torgovlya Rossijskoj Federacii uslugami v strukture rasshirennoj klassifikacii uslug (po metodologii platezhnogo balansa) za 2020 god. - Tekst: elektronnyj // Central'nyj bank Rossijskoj Federacii: [sajt]. https://cbr.ru/vfs/statistics/credit_statistics/trade/63-trade_20.xls (data obrashcheniya: 14.06.2021).

2. Eksport otdel'nyh vidov uslug po sub"ektam Rossijskoj Federacii za 2020: [sajt]. - URL: https://cbr.ru/vfs/statistics/credit_statistics/trade/exp_services_reg_20.xlsx (data obrashcheniya: 14.06.2021).

3. Chislo v"ezdnyh turistskih poezdok inostrannyh grazhdan v Rossijskuyu Federaciyu (Rosstat). - Tekst: elektronnyj // Federal'noe agentstvo po turizmu: [sajt]. - URL: https://tourism.gov.ru/contents/analytics/statistics/chislo-vezdnykh-turistskikh-poezdokinostrannykh-grazhdan-v-rossiyskuyu-federatsiyu/

(C) О.Ю. Гуревич, 2021

(C) А.Ю. Кононов, 2021

Для цитирования: Гуревич О.Ю., Кононов А. Ю. Экспорт услуг в сфере туризма // Территория новых возможностей. Вестник Владивостокского государственного университета экономики и сервиса. - 2021. - Т. 13, № 3. - С. 91-107.

For citation: Gurevich O.Yu., Kononov A. Yu. Export of services in the field of tourism, The Territory of New Opportunities. The Herald of Vladivostok State University of Economics and Service, 2021, Vol. 13, № 3, pp. 91-107.

DOI https://doi.org/10.24866/VVSU/2073-3984/2021-3/091-107

Дата поступления: 30.06.2021. 